\title{
On the Relation of the Substratum to the Metamorphosis of Scolecolepis fuliginosa (Claparède).
}

By

\author{
J. H. Day, B.Sc. (South Africa), \\ Department of Oceanography, University of Liverpool, \\ and \\ Douglas P. Wilson, M.Sc., \\ Assistant Naturalist at the Plymouth Laboratory.
}

\section{INTRODUCTION.}

WHILE investigating the Mitraria larva of Owenia fusiformis one of us (Wilson, 1932) obtained striking evidence of the important part played by the nature of the bottom in the metamorphosis of that larva. In the hope that a similar behaviour would be shown by a less specialised type of larval Polychaete experiments were undertaken by us in collaboration. The larvæ used were those of Scolecolepis fuliginosa. They were forty days old and were known to be ready to metamorphose given suitable conditions. These larvæ had been reared from the egg by J. H. D., who gives an account of the development in another paper (Day, 1934). Only a limited number were available for experiment but these have proved sufficient to yield a definite result. The major portion of the work was done in the Plymouth Laboratory, but the sands were analysed in the Department of Oceanography, University of Liverpool.

Two initial tests were first made and these giving positive indications that the grade of the bottom deposit is an important factor in metamorphosis a larger experiment was arranged. During these tests a sandy mud had been found in which the larvæ metamorphosed readily. This sandy mud and two other grades of bottom, coarser and finer, were selected and after the first day a fourth grade, a fine clean sand, was also used. A clean glass control dish with rounded corners was included, but it should be noted that in experiments of this kind the ideal control in which the larvæ could not come into contact with any surface whatever is an impossibility.

At the end of the experiment the sands and muds used were examined microscopically (by J. H. D.) and the average size of particles estimated. The sands and muds were then dried and incinerated to obtain a rough estimate of the organic content, which is expressed as a percentage of the dry weight. Care was taken that these results were not falsified by the 
loss of carbon dioxide from the calcium carbonate present. While it is not suggested that this method of determining organic content is accurate, the results obtained provide comparative values which are important and particularly striking in the mud D.

These results are tabulated below :-

$\begin{array}{cccc}\text { Vessel. } \quad \begin{array}{c}\text { Substratum. } \\ \text { A Smooth glass }\end{array} & \begin{array}{c}\text { Average diameter } \\ \text { of particles. }\end{array} & \begin{array}{c}\text { Limits of } \\ \text { variation. }\end{array} & \begin{array}{c}\text { Approximate } \\ \text { Organic Content. }\end{array} \\ \text { B Silver sand } & 0 \cdot 264 \mathrm{~mm} . & 0 \cdot 44-0 \cdot 17 \mathrm{~mm} . & 0 \cdot 2 \% \\ \text { C Sandy mud } & 0.047 \mathrm{~mm} . & 0 \cdot 34-0.03 \mathrm{~mm} . & 6.9 \% \\ \text { D Mud } & 0.063 \mathrm{~mm} . & 0 \cdot 15-0.02 \mathrm{~mm} . & 30 \cdot 0 \% \\ \text { E Fine sand } & 0.086 \mathrm{~mm} . & 0 \cdot 10-0.05 \mathrm{~mm} . & 3.0 \%\end{array}$

The silver sand B consisted of clean well-rounded grains not differing greatly in size. The fine sandy mud $\mathrm{C}$ was a mixture of fine particles with organic matter and a few larger sand grains. D was composed largely of organic debris but with a few sand grains, sponge spicules and diatom frustules. $\mathrm{E}$ had been elutriated and the variation in size of particle was small. It was dark in colour and contained about $20 \%$ calcium carbonate in the form of broken shells. On the whole the grains were sharper and more angular than those of $\mathrm{B}$.

\section{ACCOUNT OF THE Experiment.}

The experiment, details of which are tabulated on page 662 , is divided into two parts. The first part extends from noon on April 30th to noon on May 1st, 1933, when certain changes were made and thereafter continues as the second part.

\section{First Part.}

Ten larvæ picked at random from the plunger-jar were put into each of four small vessels ( 30 c.c. capacity) about half-filled with filtered seawater. These were the vessels $\mathrm{A}, \mathrm{B}, \mathrm{C}$, and $\mathrm{D}$, and the amount of sand or mud placed in the last three was just sufficient to cover the bottom with a thin layer. If too much is used it is very difficult to find burrowing larvæ when counting. A little Nitzschia was added to the water in the vessels and they were stood on black paper and covered with dark red glass discs to exclude excess light.

In all cases the larvæ explored the vessel, crawling over the bottom and attempting to burrow. If the bottom proved suitable they metamorphosed, otherwise they alternately burrowed and swam. After six hours the only change was in vessel $\mathrm{C}$ where all except two had either secreted mucus or metamorphosed. The two swimming larvæ were smaller than the rest and had possibly not reached the stage when meta- 
morphosis can take place. In less than twenty-four hours all the larvæ in $\mathrm{C}$, except the two mentioned, had become young worms, whilst no larva in the other vessels showed any sign of metamorphosis; they were all swimming actively.

\section{Second Part.}

The experiment was continued with two objects in view, first to show that the larvæ in vessels $\mathrm{A}, \mathrm{B}$, and D were ready to metamorphose, second to determine what eventually happens when larvæ are kept for long periods in conditions unfavourable to metamorphosis.

The 8 young worms in vessel $\mathrm{C}$ were removed and 5 of the 10 larvæ in each of the vessels A, B, and D transferred to C. These with the 2 left made a total of 17 . The numbers in $A, B$, and $D$ were made up to 10 by adding 5 fresh larvæ to each. The fifth vessel $\mathrm{E}$ containing 10 fresh larvæ was added to the experiment.

At the end of twenty-four hours all the larvæ in $\mathrm{C}$ except 4 had metamorphosed. Most of these had changed within three hours, and all but the 4 small larvæ mentioned had burrowed into the sand at the end of five hours. In vessels B, D, and E nothing had occurred, but in A 4 larvæ had metamorphosed. They were, however, unhealthy and soon died.

Since the course of the experiment covers several weeks the account will be more coherent if each vessel is now considered separately for its whole duration. Comparisons may be made from the table. In the accounts the transition from the first to the second part of the experiment may not be specially referred to although it should be borne in mind.

Vessel $A$. Four larvæ metamorphosed within forty-eight hours. Some diatoms and a little dust had collected at the bottom of the dish and adhered to the mucus tubes of these unhealthy worms which soon died. Meanwhile the 6 swimming larvæ were transferred to a clean vessel $\mathrm{A}^{\prime}$ where 3 of them became unhealthy and the other 3 were again transferred to a similar clean vessel $\mathrm{A}^{\prime \prime}$. One of the unhealthy larvæ in $\mathrm{A}^{\prime}$ died, but the other 2 lived to become abnormal worms, the first at the end of a week, the second after three weeks. These larvæ showed no appreciable increase in size. Of the healthy larvæ in $\mathrm{A}^{\prime \prime}$ one became a normal worm at the end of a week, a second after eighteen days, while the third died unmetamorphosed after six weeks without showing any appreciable growth.

Vessel $B$. The first larva metamorphosed on the fourth day. Four of the remaining 9 larvæ were transferred to $C^{\prime}$ to see if they would metamorphose given favourable conditions, which they did. Of the 5 left the 2 largest metamorphosed at the end of a week, another 2 within two weeks, and the last within three weeks. All worms were healthy and lived for a considerable time. 
Vessel C. At the end of the first day 8 larvæ had metamorphosed. The 8 worms were removed and 15 swimming larvæ ( 5 from each of vessels $A$, B, and D) added. Twenty-four hours later all but 4 of the 17 larvæ had metamorphosed and these did so four days later. The young worms were sent to Liverpool on May 12th. Half of them survived the journey, and 6 were still alive at the end of three months, when they varied in length from 3 to $14 \mathrm{~mm}$. The largest had lost all larval characteristics, but the smaller ones still retained the larval pigment in the anal cirri and third parapodium.

Vessel $C^{\prime}$. This had the same kind of bottom as $\mathrm{C}$ and was used to test whether larvæ in vessels $\mathrm{B}$ and $\mathrm{E}$ could metamorphose. When larvæ were transferred from these vessels on May 3rd three were unfortunately lost. Five out of the remaining 6 metamorphosed within three days and the last by the seventh day. Later 2 larvæ were transferred from $\mathrm{E}$ and they immediately began to metamorphose.

Vessel $D$. Three larvæ died on the third day. On the same day 2 metamorphosed followed by 2 more the next day. At the end of the first week there were 6 worms and 1 larva. Two days later this larva had also metamorphosed.

$V$ essel $E$. As there was no change after forty-eight hours 5 of the larvæ picked at random were transferred to vessel $\mathrm{C}^{\prime}$ where they soon metamorphosed. The remaining 5 still showing no change at the end of a week another 2 were then tested. These also metamorphosed in $\mathrm{C}^{\prime}$. No larva metamorphosed in $\mathrm{E}$ until the end of the third week when 2 of the remaining 3 larvæ became young worms. The last larva was transferred to a similar vessel $\mathrm{E}^{\prime}$. For nine weeks this individual appeared to be in perfect health, sometimes resting on the bottom, sometimes swimming vigorously. At the end of this period it underwent what seemed to be an attempt at metamorphosis during which it became unhealthy and died. These last three larvæ all grew and gained new setigers, the first two metamorphosed with 16 and 18 setigers, and when the last one died it had between 18 and 20 setigers.

\section{Discussion.}

It is evident from these results that the muddy sand in vessel $\mathrm{C}$ was a very suitable bottom for metamorphosis. This muddy sand was of a very similar nature to that in which the adult worms are found. The silver sand in B and the mud in D were evidently not so suitable; there was a delay before the larvæ metamorphosed. Since the larvæ were taken at random from the plunger-jar there is only a very slight possibility that those in $\mathrm{C}$ were more advanced than those in the other vessels. This possibility is, however, discounted by the result obtained when larvæ from $\mathrm{B}$ and $\mathrm{D}$ were transferred to $\mathrm{C}$ at noon on May 1st. Conclusive 
evidence of delay on an unsuitable bottom is however furnished by vessel E where there is no possibility of explaining the results there obtained by assuming that the larvæ were in any case not quite ready to undergo their critical change. The delay is far too great and moreover by the time the last three larvæ metamorphosed or died they had more setigers than the stage at which the larvæ first come into a condition when metamorphosis is possible. The larvæ tested by transference to a suitable substratum on the three dates, May 1st, 3rd, and 10th gave as good a proof as could be obtained that the larvæ in this dish were ready to metamorphose during the whole period. Why two of them actually metamorphosed on this bottom on May 22nd is not clear, but the fact that they did so successfully and continued to grow until they were fixed over a month later demonstrates that the bottom itself was not an impossible one for the young worms to live in, at least under laboratory conditions. During this time one had attained 72 setigers and the other 48 . The only larval features that remained were the pigment patches on the third parapodia and the anal cirri, as the third pair of eyes had disappeared and the hooded crotchets did not commence till the 23rd setiger. On the shore adults of this species are to be found rarely, if at all, in fine clean sand of this nature.

It is interesting to note that the sand in vessel $\mathrm{E}$ which proved so unattractive to Scolecolepis larvæ was of the character that would have readily induced metamorphosis in the Mitraria larva of Owenia fusiformis, while the muddy sand in vessel $\mathrm{C}$ would probably have proved unsuitable for that species.

Vessel A yields little information. As remarked above it is not an ideal control. We are unable to explain why some of the larvæ became unhealthy after the first two or three days.

\section{General Conclusions.}

While admitting that it would have been desirable to have used a larger number of larvæ had they been available we are of the opinion that it is possible to draw conclusions of considerable ecological interest. These are as follows :-

1. Scolecolepis fuliginosa larvæ do not metamorphose until they have reached the fourteen-setiger stage attained after six weeks of free swimming existence assuming the rate of development in the sea to be the same as in the laboratory.

2. When this stage is reached they make their way to the bottom and begin to burrow as soon as suitable ground is found.

3. They do not metamorphose in the plankton in mid-water and then sink to the bottom to take up adult life. 
4. Metamorphosis may be complete in twelve hours or less.

5. The suitability of the substratum evidently depends to some extent at least on the grade of the bottom deposits, a sandy mud being most suitable. Other factors, such as the organic content, may also determine the suitability.

6. Should a suitable locality not be found immediately the larva is able to postpone metamorphosis for a period that may be as long as several weeks. In the meantime the larva still actively swimming, grows slowly with the addition of new setigers.

7. If the right kind of ground is never reached an attempt is made at metamorphosis which may or may not produce a normal worm. This point is not clear and needs further investigation.

8. This ability to delay metamorphosis must greatly increase the larva's chance of reaching suitable ground, and is therefore of the utmost importance as a survival factor.

Apart from those details that are obviously specific for Scolecolepis fuliginosa these conclusions are in the main the same as those already formulated for the Mitraria larva (Wilson, 1932, p. 309). They are probably general for other species as well. The account one of us has given of the settling down and metamorphosis of the very similar larva of Polydora hoplura (Wilson, 1928b, pp. 583-585) is very suggestive that these postpone metamorphosis until they have found a suitable crevice in which to settle and begin adult life. Species that when adult are sedentary attached to rocks, shells, etc. (e.g. Pomatoceros, Sabellaria) may also suspend metamorphosis for a while until they reach some hard object on the sea bottom. In such cases, however, it would be exceedingly difficult to devise laboratory experiments to show this, as the side of any containing vessel is a suitable substratum for such larvæ. Worms that have a post-larval pelagic stage in a secreted tube (Lanice, Loimia, Arenicola, Pectinaria) will almost certainly be able to live and grow for some time after the stage at which they would normally become benthonic. Monro records (1930 and 1931) some interesting specimens of pelagic Loimia worms belonging, apparently, to the species $L$. medusa, especially one that was obtained between 250 metres and 100 metres in the middle of the South Atlantic. This specimen was at a much more advanced stage than that at which young pelagic Loimia medusa, given the opportunity, will start building their sandy tubes (Wilson, 1928a). Probably this worm had failed to reach the bottom at the usual time but had continued to grow normally in spite of an unusually long pelagic existence.

It is hoped to continue investigations along these lines whenever 
opportunity permits. It is scarcely necessary further to stress the ecological importance of such observations and their bearing on the distribution of ocean life.

\section{SUMMARY.}

Laboratory experiments indicate that larvæ of Scolecolepis fuliginosa when ready to metamorphose, are able, if necessary, to postpone metamorphosis until a substratum suitable for adult life is reached, meanwhile continuing to swim and grow for a period that may be as long as several weeks.

\section{REFERENCES.}

DAY, J. H. 1934. The Development of Scolecolepis fuliginosa (Claparède). Journ. Mar. Biol. Assoc., N.S., Vol. XIX, No. 2, pp. 633-654.

Monro, C. C. A. 1930. Polychæte Worms. Discovery Reports. Vol. II, pp. 1-222.

Monro, C. C. A. 1931. A Note on the Pelagic Phase of a Polychæte Worm belonging to the Family Terebellidæ. Ann. \& Mag. Nat. Hist., Ser. 10, Vol. VII, pp. 212-215.

Wilson, D. P. 1928a. The Post-Larval Development of Loimia medusa Sav. Journ. Mar. Biol. Assoc., N.S., Vol. XV, pp. 129-149.

Wilson, D. P. 1928b. The Larvæ of Polydora ciliata Johnston and Polydora hoplura Claparède. Journ. Mar. Biol. Assoc., N.S., Vol. XV, pp. 567-603.

Wilson, D. P. 1932. On the Mitraria Larva of Owenia fusiformis Delle Chiaje. Phil. Trans. Roy. Soc. Ldn., Ser. B, Vol. 221, pp. 231-334.

\section{EXPLANATION OF THE TABLE.}

The main results of the experiment are here tabulated to facilitate comparison between the time of metamorphosis in the different vessels. Only essential dates are recorded. The following abbreviations are used :-

a, abnormal. b, burrowing larva beginning to metamorphose. d, dead. l, accidentally lost. s, swimming larva. u, unhealthy. w, young metamorphosed worm.

The following symbols denote changes in the different vessels.

* 5 larvæ removed to $\mathrm{C}$ and 5 fresh swimming larvæ added.

18 worms removed.

215 larvæ, 5 from each of A, B and D were added, making with the 2 already present a total of 17 .

36 larvæ transferred from A to $\mathrm{A}^{\prime}$.

43 healthy larvæ transferred from $\mathrm{A}^{\prime}$ to $\mathrm{A}^{\prime \prime}$.

54 larvæ transferred from $\mathrm{B}$ to $\mathrm{C}^{\prime}$.

${ }^{6} 5$ larvæ transferred from $\mathrm{E}$ to $\mathrm{C}^{\prime}$.

72 larvæ transferred from $\mathrm{E}$ to $\mathrm{C}^{\prime}$. They started to burrow immediately.

8 larva transferred from $\mathrm{E}$ to $\mathrm{E}^{\prime}$.

${ }^{9}$ Contents of the vessel sent to Liverpool. On arrival 8 worms were still living. 


\begin{tabular}{|c|c|c|}
\hline Date & & $\begin{array}{c}\text { A } \\
\text { Clean } \\
\text { Vessel. }\end{array}$ \\
\hline April 3 & 30 Noon & $10 \mathrm{~s}$ \\
\hline ,", & 1.30 p.m. &, \\
\hline May & $\begin{array}{l}6 \text { p.m. } \\
10 \mathrm{a} . \mathrm{m} \text {. }\end{array}$ & ,, \\
\hline ," & Noon & $10 \mathrm{~s}^{*}$ \\
\hline ,, & 1 p.m. & ,, \\
\hline ," & 2.30 p.m. & ," \\
\hline ,", & $2^{5 \text { p.m. }}$ & ,", $\mathrm{s}^{3}, 4 \mathrm{uw}$ \\
\hline & 3 & \\
\hline ,, & 4 & \\
\hline ,, & 6 & \\
\hline , & $\begin{array}{l}8 \\
0\end{array}$ & \\
\hline ,", & 2 & \\
\hline , & 5 & \\
\hline 1 & 9 & \\
\hline ,, & 2 & \\
\hline & 9 & \\
\hline June & 6 & \\
\hline , $\quad 1$ & 1 & \\
\hline & 8 & \\
\hline July & 3 & \\
\hline , & 4 & \\
\hline
\end{tabular}

\begin{tabular}{|c|c|c|c|}
\hline & $A^{\prime \prime}$ & & \\
\hline Clean & Clean & Silver & Sandy \\
\hline Vessel. & Vessel. & Sand. & Mud. \\
\hline & & $10 \mathrm{~s}$ & $10 \mathrm{~s}$ \\
\hline & & ,, & $2 \mathrm{~s}, 8 \mathrm{~b}$ \\
\hline & & ,, & $\begin{array}{l}2 \mathrm{~s}, 5 \mathrm{~b}, 3 \mathrm{w} \\
2 \mathrm{~s}, 8 \mathrm{w}^{1}\end{array}$ \\
\hline & & $10 \mathrm{~s}^{*}$ & $17 \mathrm{~s}^{2}$ \\
\hline & & ," & $13 \mathrm{~s}, 4 \mathrm{~b}$ \\
\hline & & ,, & $10 \mathrm{~s}, 7 \mathrm{~b}$ \\
\hline $6 s^{3}$ & & , & $4 \mathrm{~s}, 13 \mathrm{~b}$ \\
\hline $3 \mathrm{~s}^{4}, 3 \mathrm{us}$ & $3 s^{4}$ & $9_{\mathrm{s}^{5}}^{\prime \prime} 1 \mathrm{~W}$ & $4 s, 13 w$ \\
\hline $2 \mathrm{us}, 1 \mathrm{ds}$ & . & $5 \mathrm{~s}, 1 \mathrm{w}$ & , \\
\hline & $2 \mathrm{~s}, 1 \mathrm{w}$ & $3 \mathrm{~s}, 3 \mathrm{w}$ & $17 \mathrm{w}$ \\
\hline lus, law & ,, & ," & ," \\
\hline ,, & ," & ," & ," \\
\hline , & , & " " & $8 w^{9}$ \\
\hline ," & $1 \mathrm{~s}, " 2 \mathrm{w}$ & $6 \mathrm{w}$ & , \\
\hline 2aw & , & ,, & $6 \mathrm{w}, 2 \mathrm{dw}$ \\
\hline & ,, & ,, & $6 \mathrm{w}$ \\
\hline $2 \mathrm{dw}$ & lus, $1 \mathrm{w}, 1 \mathrm{dw}$ & ," & ," \\
\hline & Dead & ? &, \\
\hline & & $2 \mathrm{w}, 4 \mathrm{dw}$ & , \\
\hline & & & , \\
\hline & & & $6 \mathrm{w}$ \\
\hline
\end{tabular}

$\mathrm{C}^{\prime}$
Sandy
Mud.

$4 \mathrm{~s}^{5}, 5 \mathrm{~s}^{6}$
$2 \mathrm{~s}, 2 \mathrm{~b}, 2 \mathrm{w}, 3 \mathrm{l}$
$1 \mathrm{~s}, 5 \mathrm{w}$
,",
$6 \mathrm{w}, 2 \mathrm{~b}^{7}$
$8 \mathrm{w}$,
,,
,
,
$7 \mathrm{w}, 1 \mathrm{dw}$
$?$
Dead

$\begin{array}{ccc}\text { D } & \text { F } & \text { F' } \\ \text { Mud. } & \text { Fine } & \text { Fine } \\ \text { Sand. } & \text { Sand. }\end{array}$

,,

10s*

4

$10 \mathrm{~s} * \quad 10 \mathrm{~s}$

", ",

,"

$5 \mathrm{~s}, 2 \mathrm{w}, 3 \mathrm{ds} \quad 10 \mathrm{~s}^{6}$

s, $6 \mathrm{w}$

$7 \mathrm{w}$

," ${ }^{2} \mathrm{~s}^{7}$

, $3 \mathrm{~s}$

?"

Dead

,',

$\mathrm{s}^{8}, 2 \mathrm{~W} \quad 1 \mathrm{~s}^{8}$

Dead

$2 \mathrm{w}$

,,

$2 \mathrm{w}$ 